\title{
GMINA JAKO PODMIOT SYSTEMU WSPIERANIA WYTWARZANIA ENERGII ELEKTRYCZNEJ Z ODNAWIALNYCH ŹRÓDEŁ ENERGII
}

\section{WPROWADZENIE}

Na przestrzeni ostatnich lat $\mathrm{z}$ coraz większym powodzeniem zaczęły rozwijać się alternatywne (względem tzw. konwencjonalnych) źródła wytwarzania energii elektrycznej, zbiorczo nazywane odnawialnymi źródłami energii (OZE). Podstawowym aktem prawnym kompleksowo regulującym zagadnienia związane z wytwarzaniem oraz mechanizmami wspierania OZE w Polsce jest ustawa z 20 lutego 2015 r. o odnawialnych źródłach energii ${ }^{1}$. Zasadnicza część tej ustawy - rozdział 4: „Mechanizmy i instrumenty wspierające wytwarzanie energii elektrycznej z odnawialnych źródeł energii, biogazu rolniczego oraz ciepła, w instalacjach odnawialnego źródła energii” - pierwotnie miał wejść w życie 1 stycznia 2016 r. Niemniej ustawodawca, mając na celu m.in. usunięcie wątpliwości prawnych i interpretacyjnych ${ }^{2}$ dotyczących praktycznego funkcjonowania mechanizmów wsparcia oraz dopuszczalności korzystania z pomocy publicznej, zdecydował się, aby istotna część u.o.z.e. weszła w życie dopiero 1 lipca 2016 r. W konsekwencji, wykorzystując czas pozostały do pełnego uruchomienia nowego systemu wsparcia OZE, głębszej analizie należy poddać poszczególne rozwiązania zaproponowane przez przepisy u.o.z.e.

Jedna z istotniejszych kwestii związanych z praktycznym stosowaniem wymienionych wyżej przepisów jest pytanie o zakres podmiotowy dotyczacy systemu wsparcia OZE. W tym powstaje pytanie, czy gmina jako jednostka samorządu terytorialnego może uczestniczyć w systemie wsparcia OZE. Dalej, kluczowe jest wskazanie potencjalnych form organizacyjno-prawnych, w których działalność gminy w przedmiotowym zakresie może być wykonywana.

\footnotetext{
${ }^{1}$ Dz. U. 2015, poz. 478 ze zm. (dalej jako: u.o.z.e.).

${ }^{2}$ Por. uzasadnienie poselskiego projektu ustawy z 29 grudnia 2015 r. o zmianie ustawy o odnawialnych źródłach energii oraz ustawy - Prawo energetyczne (Dz. U. 2015, poz. 2365, Lex Omega).
} 


\section{UNIJNE WYMOGI DOTYCZĄCE WSPIERANIA WYTWARZANIA ENERGII Z OZE}

Rozwój wytwarzania energii elektrycznej z instalacji OZE został zdeterminowany przez liczne akty prawodawstwa unijnego. Podstawową regulację w tym zakresie zawiera dyrektywa Parlamentu Europejskiego i Rady 2009/28/WE ${ }^{3}$, która wyznacza każdemu z państw członkowskich obowiązkowy cel w postaci ustalonego na konkretnym poziomie udziału energii ze źródeł odnawialnych w końcowym zużyciu energii brutto w $2020 \mathrm{r}$. Cel ten zakłada osiagnięcie przez Polskę 15-procentowego ${ }^{4}$ udziału energii ze źródeł odnawialnych w końcowym zużyciu energii brutto $\mathrm{w} 2020 \mathrm{r} .^{5}$

W związku z powyższym, aby zapewnić ekonomiczną opłacalność przedmiotowych przedsięwzięć, prawodawca unijny w art. 3 ust. 3 pkt a dyrektywy 2009/28/WE wskazał na możliwość wprowadzenia odpowiedniego systemu wsparcia wytwarzania energii elektrycznej w instalacjach OZE. Wskazany system wsparcia ma na celu redukcję negatywnych aspektów wykorzystania ekologicznej technologii wytwarzania energii elektrycznej oraz wpływ na rozwoju tych instalacji, zapewniający realizację wyznaczonych pułapów ${ }^{6}$. W związku z tym możliwość skorzystania z systemu wsparcia OZE wykorzystał również polski ustawodawca, kompleksowo ujmując tę kwestie w przepisach u.o.z.e. Należy w tym miejscu zauważyć, że prawodawca europejski wśród instrumentów wsparcia wytwarzania energii elektrycznej z OZE wyróżnił pomoc o charakterze inwestycyjnym, stanowiaca pomoc na realizację danego przedsięwzięcia oraz pomoc operacyjna, której celem jest bieżące wspieranie prowadzonej tej działalności wytwórczej. Celem niniejszego opracowania jest analiza prawna możliwości korzystania przez gminę z instrumentów pomocy operacyjnej, uregulowanych w przepisach u.o.z.e.

Przepisy dyrektywy 2009/28/WE nie zawierają żadnych przepisów regulujacych kwestię, jakim konkretnie podmiotom państwa członkowskie moga przyznać określoną pomoc w ramach systemu wsparcia OZE. Jednakże, jak słusznie podkreśla się w literaturze ${ }^{7}$, system wsparcia OZE należy zakwalifikować

${ }^{3}$ Dyrektywa Parlamentu Europejskiego i Rady 2009/28/WE z 23 kwietnia 2009 r. w sprawie promowania stosowania energii ze źródeł odnawialnych zmieniająca i w następstwie uchylająca dyrektywę 2001/77/WE oraz 2003/30/WE, Dz. Urz. UE L 140, 14 sierpnia 2009 r., s. 16 (dalej jako: dyrektywa 2009/28/WE).

${ }^{4}$ Zob. Załącznik I do dyrektywy 2009/28/WE Krajowe cele ogólne w zakresie udziału energii ze źródeł odnawialnych w końcowym zużyciu energii brutto w $2020 \mathrm{r}$.

${ }^{5}$ Niemniej - obserwując aktualne cele polityki klimatyczno-energetycznej do 2030 r., przyjęte w Konkluzjach Rady Europejskiej z 23 i 24 października 2014 r. (EUCO 169/14), zwiększenie do co najmniej $27 \%$ udziału energii ze źródeł odnawialnych w energii zużywanej w całej UE - należy domniemywać, że cele krajowe dla poszczególnych państw członkowskich również ulegną podwyższeniu.

${ }^{6} \mathrm{Na}$ konieczność zastosowania przemyślanej strategii publicznego wsparcia inwestycji w zakresie OZE wskazuja T. Henzelmann, P. Hoff, Zielone finansowanie $i$ nowe „zielone złoto”, w: R. Berger (red.), Zielony wzrost, zielony zysk. Jak zielona rewolucja stymuluje gospodarkę, Warszawa 2014, s. 280-285.

${ }^{7}$ Zob. D. Kobiałko, Analiza ustawy o odnawialnych źródtach energii z 20 lutego 2015 roku $w$ świetle przepisów unijnych dotyczacych pomocy publicznej, „Przegląd Prawniczy Europejskiego Stowarzyszenia Studentów Prawa ELSA Poland” 2015, z. 3, s. 167-183; W. Szopiński, Czy syste- 
jako system pomocy publicznej, a w związku z tym powinien on być zgodny z ogólną regulacją określająca prawne ramy dozwolonej pomocy publicznej w państwach członkowskich UE. Jednocześnie trzeba zaznaczyć, że zagadnienie ogólnych reguł konkurencji mającej znaczenie dla rynku wewnętrznego, a w tym także szczegółowy obszar, jakim jest udzielanie pomocy publicznej, należy do wyłącznej kompetencji $\mathrm{UE}^{8}$. Nie wdając się jednak w szczegóły, należy stwierdzić, że podstawowa regulacja w tym zakresie znajduje się w art. 107 TfUE $^{9}$. Przepis ten wskazuje, że pomoc publiczna polega m.in. na sprzyjaniu niektórym przedsiębiorstwom. W związku z powyższym należy również podkreślić, że każdy zaproponowany przez państwo członkowskie system wsparcia OZE, uznawany za zgodny z rynkiem wewnętrznym na podstawie generalnych ${ }^{10}$ bądź indywidualnych ${ }^{11}$ procedur weryfikacyjnych wskazanych w TfUE, może być kierowany jedynie do przedsiębiorstw (podmiotowo przedsiębiorców).

Prawodawca unijny posługuje się pojęciem „przedsiębiorstwo” (ang. undertakings, fr. entreprises, niem. Unternehmen) w znaczeniu podmiotowym, co oznacza, że „przedsiębiorstwo” jest podmiotem praw i obowiązków wynikających z poszczególnych przepisów unijnych. Niestety, choć pojęcie „przedsiębiorstwo" pojawia się w przepisach TfUE wielokrotnie, to brak w nich jego legalnej definicji.

Europejski Trybunał Sprawiedliwości w swoim orzecznictwie definiuje pojęcie „przedsiębiorstwo” niezwykle szeroko: jako „każdą jednostkę zaangażowaną w działalność gospodarczą, bez względu na jej formę prawna i sposób finansowania" (sprawa Höfner) ${ }^{12}$. Z kolei przez działalność gospodarczą (ang. economic activity) rozumie się każdą aktywność o charakterze handlowym czy gospodarczym. Jej zasadniczym celem wcale nie musi być

my wsparcia dla energii z odnawialnych źródet przewidziane w projekcie ustawy o odnawialnych źródtach energii można uznać za pomoc publiczna?., „Przegląd Prawniczy Europejskiego Stowarzyszenia Studentów Prawa ELSA Poland” 2015, z. 3, 153-166.

${ }^{8}$ Zob. P. Saganek, Komentarz do art. 3 Traktatu o funkcjonowaniu Unii Europejskej, w: M. Wasik, N. Półtorak, A. Wróbel (red.), Traktat o funkcjonowaniu Unii Europejskiej, Lex Omega, nr 124517.

${ }_{9}$ Traktat o funkcjonowaniu Unii Europejskiej (Dz. Urz. UE C 326, 26 października 2012 r., s. 47).

${ }^{10}$ Zob. art. 42 rozporządzenia Komisji (UE) nr 651/2014 z 17 czerwca 2014 r. uznającego niektóre rodzaje pomocy za zgodne z rynkiem wewnętrznym w zastosowaniu art. 107 i 108 Traktatu (Dz. Urz. UE L 187, 1 lipca 2014 r., s. 1), uznającego za zgodną z rynkiem wewnętrznym pomoc operacyjną przyznawaną na propagowanie energii elektrycznej ze źródeł odnawialnych, spełniającej jednocześnie wymagania wskazane w tym rozporządzeniu.

${ }^{11}$ System wsparcia OZE może podlegać procedurze indywidualnej notyfikacji opisanej w art. 108 ust. 3 TfUE. Komisja Europejska, rozpatrując zagadnienie pomocy publicznej na energię ze źródeł odnawialnych, kieruje się Komunikatem Komisji - Wytyczne w sprawie pomocy publicznej na ochronę środowiska i cele związane z energią w latach 2014-2020 (Dz. Urz. UE C 200, 28 czerwca 2014 r., s. 1).

12 ,The concept of an undertaking encompasses every entity engaged in an economic activity, regardless of the legal status of the entity and the way in which it is financed" (tłum. E. Kosinski). Orzeczenie z 23 kwietnia 1991 r. w sprawie C-41/90 - Klaus Höfner, Fritz Elser przeciwko Macroton GmbH (Höfner), Zb. Orz. 1991, s. I-1979, w szczególności ust. 58, 59 i 62. 
osiagnięcie zysku ${ }^{13}$. Co więcej, działalność ta w ogóle może być pozbawiona celów gospodarczych ${ }^{14}$.

Potwierdzeniem tezy o bardzo szerokim ujęciu pojęcia „przedsiębiorstwo" jako podmiotu mogącego uzyskać dozwolona pomoc publiczna jest treść art. 1 Załącznika I do rozporządzenia Komisji (UE) nr 651/2014 z 17 czerwca 2014 r. uznającego niektóre rodzaje pomocy za zgodne z rynkiem wewnętrznym w zastosowaniu art. 107 i 108 Traktatu $^{15}$. W wymienionym przepisie prawodawca unijny wskazuje, że za przedsiębiorstwo uważa się podmiot prowadzący działalność gospodarczą bez względu na jego formę prawną. W szczególności należy wskazać, że za przedsiębiorstwo uznaje się jednostkę samorządu terytorialnego prowadzaca działalność gospodarczą w zakresie dystrybucji energii elektrycznej ${ }^{16}$. Należy zatem stwierdzić, że w świetle prawa europejskiego jednostki samorządu terytorialnego mogą być uznane za przedsiębiorstwa, jeżeli prowadzą działalność gospodarczą m.in. w zakresie dostarczania energii elektrycznej. W konsekwencji wydaje się, że komunalne przedsiębiorstwa wytwarzające energię elektryczną z OZE mogą być objęte systemem wsparcia OZE, tworzonym przez poszczególne państwa członkowskie UE ${ }^{17}$. Jednakże w tym zakresie decydujące znaczenie będą miały przepisy krajowe tych państw, regulujące, czy i na jakich zasadach jednostki samorządu terytorialnego moga podejmować działalność gospodarczą w sektorze wytwarzania energii z OZE.

\section{CHARAKTER DZIAŁALNOŚCI GMINY W SFERZE WYTWARZANIA ENERGII ELEKTRYCZNEJ}

Zgodnie z art. 7 ust. 1 ustawy z 8 marca 1990 r. o samorządzie gminnym ${ }^{18}$,zaspokajanie zbiorowych potrzeb wspólnoty należy do zadań własnych gminy". W tym pośród zadań gminy wymieniony expressis verbis jest obszar

${ }_{13}$ Zob. E. Kosiński, Rodzaje i zakres sektorowych wyłaczeń zastosowania ogólnych reguł ochrony konkurencji, Poznań 2007, s. 121 i n. Zob. nadto: A. Kaczorowska, European Union Law, 3rd ed., London-New York 2013, s. 764-765; P. S. R. F. Mathijsen, A Guide to European Union Law, London 2007, s. 281-282; A. Arnull et al., Wyatt and Dashwood's European Union Law, 5th ed., London 2006, s. 973-979; E. Szyszczak, A. Cygan, Understanding EU Law, London 2005, s. 155-156.

${ }^{14}$ Zob. orzeczenia TSUE: 155/73 - Wtochy przeciwko Sacchi (Zb. Orz. 1974, s. 409), 209/78 Van Landewyck przeciwko Komisji (Zb. Orz. 1980, s. 3125; CMLR 1981, nr 3, s. 134), C-244/94 - Fédération Française des Sociétés d'Assurance przeciwko Ministere de l'Agriculture et de la Peche (Zb. Orz. 1995, s. I-4013; CMLR 1996, nr 4, s. 536), C-67/96 - Albany International BV przeciwko Stichting Bedrijfspensioenfonds Texielindustrie (Zb. Orz. 1999, s. I-5751; CMLR 2000, $\mathrm{nr}$ 4, s. 446). Inaczej twierdzi A. Cieśliński, Wspólnotowe prawo gospodarcze. Swobody rynku wewnętrznego, Warszawa 2008, s. 454.

${ }_{15}$ Dz. Urz. UE L 187, 1 lipca 2014 r., s. 1.

${ }^{16}$ Zob. orzeczenie TSUE z 23 kwietnia 1993 r. w sprawie C-393/92 - Almelo, Lex, nr 118349; G. Materna, Pojęcie przedsiębiorcy, Lex, nr 108073; M. Etel, Pojęcie przedsiębiorcy w prawie polskim i prawie Unii Europejskiej oraz w orzecznictwie sqdowym, Lex Omega, nr 141275.

${ }^{17}$ Szerzej na temat pomocy publicznej na rzecz przedsiębiorstw świadczących usługi w ogólnym interesie gospodarczym zob. w: S. Dudzik, Pomoc państwa dla przedsiębiorstw publicznych w prawie Wspólnoty Europejskiej. Między neutralnościq a zaangażowaniem, Lex Omega, nr 33918.

${ }_{18}$ T.jedn.: Dz. U. 2015, poz. 1515 ze zm. (dalej jako: u.s.g.). 
(obszary) obejmujący sprawy „wodociagów i zaopatrzenia w wodę, kanalizacji, usuwania i oczyszczania ścieków komunalnych, utrzymania czystości i porządku oraz urządzeń sanitarnych, wysypisk i unieszkodliwiania odpadów komunalnych, zaopatrzenia w energię elektryczną i cieplną oraz gaz" (art. 7 ust. 1 pkt 3 u.s.g.).

Wydaje się, że działalność gminy w sferze wytwarzania energii elektrycznej z OZE można uznać za pozostajacą w sferze zadań własnych z obszaru zaopatrzenia w energię elektryczną. Zauważyć niemniej należy, że w takim przypadku to nie gmina bezpośrednio zaopatruje w energię elektryczna swoich mieszkańców, a czyni to dane przedsiębiorstwo energetyczne.

Wszystkie pozostałe ustawy samorządowe w Polsce wskazują na nałożone na jednostki samorządu terytorialnego zadania własne - „zadania publiczne o znaczeniu lokalnym” ${ }^{19}$. Zgodnie z art. 166 ust. 1 Konstytucji RP ${ }^{20}$ „zadania publiczne służące zaspokajaniu potrzeb wspólnoty samorządowej są wykonywane przez jednostkę samorządu terytorialnego jako zadania własne" ${ }^{21}$. Tak więc art. 4 ust. 1 ustawy z 5 czerwca 1998 r. o samorządzie powiatowym ${ }^{22}$ oraz art. 14 ust. 1 ustawy z 5 czerwca 1998 r. o samorządzie województwa ${ }^{23}$ wskazują na ciążące na jednostkach samorządu terytorialnego w Polsce określone zadania publiczne. Zgodnie z art. 4 ust. 1 u.s.p. „powiat wykonuje określone ustawami zadania publiczne o charakterze ponadgminnym”. Z kolei według art. 14 ust. 1 u.s.w. samorząd ten ,wykonuje zadania o charakterze wojewódzkim określone ustawami”. Brak jednak w wymienionych ustawach samorządowych, regulujących ustrój i zadania samorządu powiatu i województwa, obszarów działalności samorządu wymienionych w art. 7 ust. 1 pkt 3 u.s.g. Co więcej, obszarów tych nie można przypisać samorządowi powiatowemu, albowiem ustawa regulująca wymieniony samorząd wprowadza enumeratywna listę zadań tego samorządu i brak w niej zaopatrzenia w energię elektryczną ${ }^{24}$. W przypadku województwa natomiast przypisanie przedmiotowego zadania byłoby możliwe, ponieważ właściwy przepis ustawy regulujaceej ustrój i zadania samorządu województwa (art. 14 ust. 1 u.s.w.) zawiera katalog otwarty tych zadań. Możliwe byłoby więc nałożenie na samorząd województwa zadań w zakresie energetyki ${ }^{25}$.

Problematyczne jest natomiast, czy przedmiotowa w niniejszych rozważaniach działalność gminy polegająca na wytwarzaniu energii elektrycznej z OZE zaliczyć można do zadań użyteczności publicznej (zadań o charakterze użyteczności publicznej). Zauważyć należy, że o ile w latach dziewięćdziesią-

${ }_{19}$ P. Dobosz, w: P. Chmielnicki (red.), Ustawa o samorzadzie gminnym. Komentarz, Warszawa 2013, s. 173.

${ }^{20}$ Konstytucja RP z 2 kwietnia 1997 r., Dz. U. Nr 78, poz. 483 ze zm.

21 Por. M. Szydło, Ustawa o gospodarce komunalnej. Komentarz, Warszawa 2008, s. 39-40.

${ }^{22}$ T.jedn.: Dz. U. 2015, poz. 1445 ze zm. (dalej jako: u.s.p.).

${ }^{23}$ T.jedn.: Dz. U. 2015, poz. 1392 ze zm. (dalej jako: u.s.w.).

${ }^{24}$ Por. m.in. wyrok WSA we Wrocławiu z 26 kwietnia 2006 r., IV SA/Wr 259/05. Zob. R. Cybulska, Komentarz do art. 4 ustawy o samorzadzie powiatowym, w: B. Dolnicki (red.), Ustawa o samorzadzie powiatowym. Komentarz, wyd. 2, Lex Omega, nr 8439.

${ }_{25}$ Zob. R. Cybulska, Komentarz do art. 14 ustawy o samorzqdzie województwa, w: B. Dolnicki (red.), Ustawa o samorzqdzie województwa. Komentarz, Lex Omega, nr 8704. 
tych XX w. powszechne było, zarówno w doktrynie prawa, jak i w orzecznictwie Naczelnego Sądu Administracyjnego, utożsamianie zadań własnych gminy z zadaniami użyteczności publicznej ${ }^{26}$, to aktualnie za utrwalony można uznać pogląd o zróżnicowaniu tych pojęćc ${ }^{27}$.

Terminy „zadania użyteczności publicznej” oraz „zadania o charakterze użyteczności publicznej” (w istocie tożsame pojęciowo) pojawiają się bezpośrednio w ustawie o samorządzie gminnym w art. 9 ust. 2, 3 i 4 . Zgodnie z definicją zadań użyteczności publicznej, zawartą w art. 9 ust. 4 u.s.g., zadaniami tymi sa „zadania własne gminy, określone w art. 7 ust. 1, których celem jest bieżące i nieprzerwane zaspokajanie zbiorowych potrzeb ludności w drodze świadczenia usług powszechnie dostępnych". Wymieniona definicja znajduje powtórzenie w ustawie z 20 grudnia 1996 r. o gospodarce komunalnej28. Według art. 1 ust. 2 u.g.k.: „gospodarka komunalna obejmuje w szczególności zadania o charakterze użyteczności publicznej, których celem jest bieżące i nieprzerwane zaspokajanie zbiorowych potrzeb ludności w drodze świadczenia usług powszechnie dostępnych". Z kolei zgodnie z art. 1 ust. 1 u.g.k. zakresem regulacji ustawowej objęte są zasady i formy gospodarki komunalnej jednostek samorządu terytorialnego, polegajace na wykonywaniu przez te jednostki zadań własnych w celu zaspokojenia zbiorowych potrzeb wspólnoty samorządowej. W tym miejscu podkreślenia wymaga, że wspólnotę samorządową należy rozumieć szeroko, obejmując zakresem podmiotowym tego pojęcia także osoby niezameldowane na terenie danej gminy na pobyt stały. Podstawowym kryterium w tym wypadku jest występowanie potrzeby wymagajacej zaspokojenia ${ }^{29}$.

Stwierdzić należy, że aktywność gminy polegająca na wytwarzaniu energii z OZE, na zasadach określonych przez u.o.z.e., nie spełnia wymogu bieżącego i nieprzerwanego zaspokajania zbiorowych potrzeb ludności w drodze świadczenia usług powszechnie dostępnych, skoro bezpośrednio przedmiotowym zaspokajaniem potrzeb w sferze energii elektrycznej w istocie zajmują się przedsiębiorstwa energetyczne działające na podstawie ustawy z 10 kwietnia 1997 r. - Prawo energetyczne ${ }^{30}$. Tak więc gmina ani nie świadczy (nie dostarcza) usług w omawianym zakresie, ani też ich bezpośrednio nie organizuje przez tworzenie właściwych warunków technicznych, organizacyjnych, finansowych itp. ${ }^{31}$

${ }_{26}$ Zob. w tym zakresie przegląd literatury oraz orzecznictwa NSA w: M. Szydło, op. cit., s. 133.

${ }^{27}$ W literaturze zauważa się, że pojęcie zadań własnych samorządu terytorialnego (zaspokajanie zbiorowych potrzeb wspólnoty) „pozostaje w pozytywnej korelacji” z pojęciem zadań o charakterze użyteczności publicznej. P. Dobosz, op. cit., s. 173. Zob. nadto wyrok NSA z 16 maja 2006 r., II OSK 288/06 (OSS 2006, nr 4, poz. 108), gdzie wyraźnie stwierdza się, że nie wszystkie zadania własne gminy z art. 7 ust. 1 u.s.g. stanowią jednocześnie zadania o charakterze użyteczności publicznej, oraz szerokie rozważania w tym zakresie: P. Chmielnicki, w: idem (red.), Ustawa o samorzqdzie gminnym..., s. 181-182, oraz M. Szydło, op. cit., s. 132 i n.

28 T.jedn.: Dz. U. 2011, Nr 45, poz. 236 ze zm. (dalej jako: u.g.k.).

${ }_{29}$ Zob. liczne wyroki sądów administracyjnych: NSA z 23 listopada 2005 r., I OSK 1029/05 (Lex, nr 196758); NSA z 24 stycznia 2012 r., I OSK 2012/11 (Lex, nr 1120647); WSA w Gliwicach z 12 kwietnia 2012 r., II SA/Gl 827/11.

${ }^{30}$ T.jedn.: Dz. U. 2012, poz. 1059 ze zm. (dalej jako: u.p.e.).

31 Por. M. Szydło, op. cit., s. 135-137. 
Brak więc korelacji w przedmiotowym przypadku pomiędzy zadaniem własnym gminy a zadaniem użyteczności publicznej. W konsekwencji wytwarzanie przez gminę energii elektrycznej z OZE zaliczyć należy do działalności wykraczającej poza sferę użyteczności publicznej, a tym samym działalność ta stanowić będzie działalność gospodarczą w rozumieniu art. 2 ustawy z 2 lipca 2004 r. o działalności gospodarczej ${ }^{32}$.

Zauważyć należy na marginesie niniejszych rozważań, że odmiennie traktowany może być przypadek wytwarzania przez gminę energii elektrycznej z OZE i przeznaczenie tak uzyskanej energii wyłącznie na własne potrzeby, np. na oświetlenie uliczne, oświetlenie budynków użyteczności publicznej itp. Niemniej wymieniony przypadek (który można zaliczyć do sfery użyteczności publicznej) zasługuje na odrębna analizę prawną i osobne opracowanie (podejmujące także problematykę możliwości korzystania z instrumentów pomocy o charakterze inwestycyjnym).

\section{GMINA JAKO PRZEDSIĘBIORCA W SFERZE WYTWARZANIA ENERGII ELEKTRYCZNEJ. PRAWNE FORMY DZIAŁALNOŚCI}

Zgodnie z art. 4 ust. 1 ustawy z 2 lipca 2004 r. o swobodzie działalności gospodarczej: „przedsiębiorca w rozumieniu ustawy jest osoba fizyczna, osoba prawna i jednostka organizacyjna niebędacca osobą prawna, której odrębna ustawa przyznaje zdolność prawna - wykonująca we własnym imieniu działalność gospodarczą". Podobnie stanowi art. $43^{1}$ Kodeksu cywilnego ${ }^{33}$. W świetle powyższej definicji należy stwierdzić, że gmina, podejmując i wykonując działalność gospodarcza, jest przedsiębiorcą zarówno na gruncie u.s.d.g., jak i k.c.

Zauważyć należy, że w literaturze obecny jest pogląd przeciwny, zgodnie z którym wykonywania zadań własnych przez jednostki samorządu terytorialnego (w tym gminę), tj. prowadzenie gospodarki komunalnej przede wszystkim w sferze użyteczności publicznej, nie należy utożsamiać z działalnościa gospodarcza, a tym samym gmina nie może być uznawana za przedsiębiorcę ${ }^{34}$. Podstawowym argumentem przywoływanym przez zwolenników wskazanej tezy jest brak głównego celu charakteryzującego działalność gospodarczą w działalności samorządu terytorialnego, tj. celu zarobkowego ${ }^{35}$.

\footnotetext{
${ }^{32}$ T.jedn.: Dz. U. 2015, poz. 584 (dalej jako: u.s.d.g.).

${ }^{33}$ Ustawa z 23 kwietnia 1964 r. - Kodeks cywilny, t.jedn.: Dz. U. 2014, poz. 121 ze zm. (dalej jako: k.c.).

${ }^{34}$ Zob. m.in. przedstawiony poglad K. Bandarzewskiego, w: P. Chmielnicki (red.), Komentarz do ustawy o samorzadzie gminnym, Warszawa 2004, s. 117-118. Zob. także K. Bandarzewski, w: P. Chmielnicki (red.), Ustawa o samorzadzie gminnym..., s. 272-274 (,,[...] gospodarka komunalna w sferze użyteczności publicznej nie jest działalnościa gospodarczą", s. 274). Zob. także K. Jaroszyński, w: R. Hauser, Z. Niewiadomski, Ustawa o samorzqdzie gminnym. Komentarz z odniesieniem do ustaw o samorzqdzie powiatowym i samorzadzie województwa, Warszawa 2011, s. 137-138 (,,[...] aktywność jednostek samorządu terytorialnego na rynku nie może być kwalifikowana jako działalność gospodarcza w rozumieniu ustawy o swobodzie działalności gospodarczej”, s. 138).

${ }_{35}$ Por. T. Kocowski, Gmina jako przedsiębiorca w społecznej gospodarce rynkowej, w: T. Kocowski, J. Gola (red.), Przedsiębiorca w społecznej gospodarce rynkowej, Prace Naukowe Uniwersytetu Ekonomicznego we Wrocławiu, nr 372, Wrocław 2014, s. 203-204.
} 
Nie można zgodzić się z przedstawionym poglądem. Jednostki samorządu terytorialnego, w tym gminę, należy uznać za przedsiębiorców w obszarze wykonywanej przez nie działalności gospodarczej. Działalnością gospodarczą jest z kolei działalność samorządu terytorialnego wykonywana odpłatnie i przynosząca (potencjalnie bądź realnie) zysk. W konsekwencji za działalność gospodarczą uznać należy zarówno gospodarkę komunalną poza sfera użyteczności publicznej, jak i znaczną część gospodarki komunalnej w sferze użyteczności publicznej, gdzie gmina występuje jako uczestnik obrotu gospodarczego (w tej sferze o kwalifikacji danej działalności jako działalności gospodarczej decydować będzie odpłatność danych świadczeń czy usług oraz cel zarobkowy, bez względu na ewentualne polityczne deklaracje władz jednostki samorządu terytorialnego ${ }^{36}$.

Gmina bezpośrednio może być przedsiębiorca tylko wtedy, gdy prowadzi gospodarkę komunalną w sferze użyteczności publicznej, w tej sferze bowiem dopuszczalne prawem są formy organizacyjno-prawne jednostek sektora finansów publicznych ${ }^{37}$, tj. samorządowe zakłady budżetowe (art. 2 , art. 6 i art. 7 u.g.k.). Co więcej, art. 14 pkt 3 ustawy z 27 sierpnia 2009 r. o finansach publicznych ${ }^{38}$ explicite wskazuje, że zadania własne jednostki samorządu terytorialnego w zakresie wodociagów i zaopatrzenia w wodę, kanalizacji, usuwania i oczyszczania ścieków komunalnych, utrzymania czystości i porządku oraz urządzeń sanitarnych, wysypisk i unieszkodliwiania odpadów komunalnych, zaopatrzenia w energię elektryczną i cieplną oraz gaz mogą być wykonywane przez samorządowe zakłady budżetowe ${ }^{39}$.

Podkreślić należy, że gmina, prowadząc działalność w ramach gospodarki komunalnej, staje się przedsiębiorca w zakresie tej właśnie działalności niejako cząstkowo, fragmentarycznie, w tym jedynie obszarze ${ }^{40}$. Gmina bowiem

\footnotetext{
${ }^{36}$ Por. podobne stanowisko m.in. w: S. Dudzik, Działalność gospodarcza samorzqdu terytorialnego - problematyka prawna, Kraków 1998, s. 107-109, s. 306; M. Szydło, op. cit., s. 35-38, oraz s. 390-395 (szczególnie s. 38 „[...] działalność określana mianem gospodarki komunalnej może mieć zarówno charakter działalności gospodarczej, jak też charakter działalności niegospodarczej, administracyjnej"); T. Kocowski, op. cit., s. 205-208; A. Matan, w: B. Dolnicki (red.), Ustawa o samorzadzie gminnym. Komentarz, Warszawa 2016, s. 293-298 (autor ten nietrafnie, bez większego uzasadnienia, traktuje każdy przejaw gospodarki komunalnej zarówno w sferze poza użytecznością publiczna, jak i w sferze użyteczności publicznej, jako działalność gospodarczą w rozumieniu art. 2 u.s.d.g.). Zob. nadto orzecznictwo sądów administracyjnych: wyrok WSA w Poznaniu z 12 maja 2011 r., IV SA/Po 246/11 (http://orzeczenia.nsa.gov.pl/ [dostęp: 19.01.2016], oraz wyrok WSA w Bydgoszczy z 12 września 2007 r., II SA/Bd 537/07 (Lex, nr 418145).

${ }^{37}$ Zob. obszernie w: K. Winiarska, Formy organizacyjno-prawne jednostek sektora finansów publicznych, „Zeszyty Naukowe Uniwersytetu Szczecińskiego” nr 625 („Finanse, Rynki Finansowe, Ubezpieczenia" nr 32), 2011, s. 677 i n.

${ }^{38}$ T.jedn.: Dz. U. 2013, poz. 885 ze zm. (u.f.p.).

39 Tym samym działalność w zakresie zaopatrywania w energię elektryczną traktowana jest przez u.f.p. jako gospodarka komunalna w sferze zadań użyteczności publicznej. Jednakże podkreślenia po raz kolejny wymaga, że samo wytwarzanie energii elektrycznej, bez świadczenia bezpośrednio na rzecz ludności usług powszechnie dostępnych, sprawia, że działalność taka nie może być traktowana jako działalność w sferze zadań użyteczności publicznej.

${ }^{40} \mathrm{H}$. Gronkiewicz-Waltz i K. Jaroszyński piszą o przedsiębiorcach „z natury” oraz o przedsiębiorcach „ubocznie” (eidem, w: H. Gronkiewicz-Waltz, M. Wierzbowski (red.), Prawo gospodarcze. Zagadnienia administracyjnoprawne, wyd. 4, Warszawa 2015, s. 225-226).
} 
nie stanowi przedsiębiorcy sensu stricto, działalność gospodarcza oraz bycie przedsiębiorca (status przedsiębiorcy) nie jest jej zasadniczą istotą ${ }^{41}$.

Poza sferą użyteczności publicznej gmina nie może prowadzić gospodarki komunalnej w formie samorządowych zakładów budżetowych (art. 7 u.g.k.). Możliwe jest natomiast tworzenie spółek prawa handlowego (spółek z ograniczoną odpowiedzialnością i akcyjnych, oraz w przypadku realizacji partnerstwa publiczno-prywatnego - spółek komandytowych i komandytowo-akcyjnych; art. 10 ust. 1 i art. 9 ust. 1 - 2 u.g.k.).

W konsekwencji należy stwierdzić, że w przypadku działalności gminy polegającej na wytwarzaniu energii elektrycznej z OZE działalność taka mogłaby być wykonywana wyłącznie w formie spółek prawa handlowego. Oznacza to, że bezpośrednimi podmiotami podejmującymi i wykonującymi działalność będa te właśnie spółki i to one będą posiadały status przedsiębiorcy (art. 4 ust. 1 u.s.d.g, art. 3 pkt 12 u.p.e., art. 36 ustawy z 20 sierpnia 1997 r. o Krajowym Rejestrze Sądowym ${ }^{42}$ ).

Niemniej należy zauważyć, że skoro działalność gminy polegająca na wytwarzaniu energii elektrycznej z OZE stanowi działalność poza sferą użyteczności publicznej, to podlega ona regulacji zawartej w art. 10 ust. 1-3 u.g.k. Na przykład poza sferą użyteczności publicznej gmina może tworzyć spółki prawa handlowego i przystępować do nich, jeżeli łącznie zostaną spełnione następujące warunki: po pierwsze - istnieją niezaspokojone potrzeby wspólnoty samorządowej na rynku lokalnym; po drugie - występujące w gminie bezrobocie w znacznym stopniu wpływa ujemnie na poziom życia wspólnoty samorządowej, a zastosowanie innych działań i wynikających z obowiązujących przepisów środków prawnych nie doprowadziło do aktywizacji gospodarczej, a w szczególności do znacznego ożywienia rynku lokalnego lub trwałego ograniczenia bezrobocia.

Dalej, zgodnie z ust. 2 art. 10 u.g.k., gmina może także tworzyć spółki prawa handlowego i przystępować do nich, jeżeli zbycie składnika mienia komunalnego mogącego stanowić wkład niepieniężny gminy do spółki albo też rozporządzenie nim w inny sposób spowoduje dla gminy poważną stratę majątkową.

Co więcej, zgodnie z ust. 3 art. 10 u.g.k. wszystkie wymienione wyżej ograniczenia nie mają zastosowania do posiadania przez gminę akcji lub udziałów spółek zajmujących się czynnościami bankowymi, ubezpieczeniowymi oraz działalnością doradcza, promocyjna, edukacyjną i wydawniczą na rzecz samorządu terytorialnego, a także innych spółek ważnych dla rozwoju gminy (w tym przepis wskazuje na kluby sportowe działających w formie spółki kapitałowej).

${ }^{41}$ Zob. dla porównania wyrok NSA w sprawie posiadania statusu przedsiębiorcy przez Agencję Mienia Wojskowego oraz zawartą tam argumentację: wyrok z 18 sierpnia 2015 r., II FSK 2118/13 (http://orzeczenia.nsa.gov.pl/ [dostęp: 1.02.2016]). Zob. nadto wyrok WSA we Wrocławiu z 19 marca 2008 r., I SA/Wr 1785/07 (http://www.orzeczenia-nsa.pl/wyrok/i-sa-wr-834-12/podatki_od_nieruchomosci_podatkowe_postepowanie/2ef394f.html [dostęp: 12.02.2016]).

${ }^{42}$ T.jedn.: Dz. U. 2015, poz. 1142 ze zm. 
Co prawda w literaturze wyrażany jest pogląd o konieczności zawężającej interpretacji pojęcia „spółka ważna dla rozwoju gminy”43 (a w zasadzie kryjącego się za wymienioną fraza pojęcia „spółka prowadząca ważną dla rozwoju gminy działalność", gdyż to działalność takiej spółki jest kluczowa, nie zaś sam podmiot ją wykonujący), jednakże można uznać, że wytwarzanie energii elektrycznej z OZE, i tym samym uczestnictwo w wielkim energetycznym i ekologicznym projekcie (m.in. dekarbonizacja energetyki, obniżenie poziomu emisji dwutlenku węgla itd.), określanym mianem trzeciej rewolucji przemysłowej $^{44}$, stanowi działalność ważną nie tylko dla danej gminy, lecz dla całego kraju i ludzkości.

\section{WYTWÓRCA JAKO PODMIOT WYTWARZAJĄCY ENERGIĘ ELEKTRYCZNĄ W INSTALACJI OZE}

Polski ustawodawca, odwołując się w tym zakresie do przepisów unijnych, zdecydował się na skonstruowanie odpowiednich mechanizmów i instrumentów wpływających na dalszy rozwój wytwarzania energii ze źródeł odnawialnych, tak aby osiagnąc założony 15-procentowy udział OZE w krajowym zużyciu energii. W związku z powyższym zasadnicza część przepisów zawartych w u.o.z.e. kierowana jest do wytwórców energii elektrycznej z instalacji OZE. Definicja legalna pojęcia wytwórcy jako podmiotu mogącego korzystać z poszczególnych instrumentów wsparcia OZE uregulowana jest w art. 2 pkt 39 u.o.z.e. Zgodnie $\mathrm{z}$ wymienionym przepisem wytwórca jest podmiot, który ma siedzibę lub miejsce zamieszkania na terytorium państwa członkowskiego UE, Konfederacji Szwajcarskiej lub państwa członkowskiego Europejskiego Porozumienia o Wolnym Handlu (EFTA) - strony umowy o Europejskim Obszarze Gospodarczym, wytwarzający energię elektryczną lub ciepło z odnawialnych źródeł energii lub wytwarzający biogaz rolniczy w instalacjach odnawialnego źródła energii znajdującego się na terytorium RP lub w wyłącznej strefie ekonomicznej.

Warto wskazać, że powyższa definicja ma charakter podmiotowo-przedmiotowy. Łączna realizacja wszystkich jej elementów kwalifikuje dany podmiot jako wytwórcę w rozumieniu u.o.z.e. Tak więc w ujęciu podmiotowym wytwórca musi być osobą prawną albo innym podmiotem prawa - majaccym określona siedzibę, bądź też w przypadku osób fizycznych - mających określone miejsce zamieszkania. Natomiast aspekt przedmiotowy tej definicji wskazuje, że wytwórca musi prowadzić określoną działalność gospodarczą polegająca na wytwarzaniu m.in. energii elektrycznej w instalacjach odnawialnego źródła energii (dalej: instalacja OZE), znajdujących się na terenie RP albo jej wyłącznej strefy ekonomicznej.

${ }^{43}$ Zob. C. Banasiński, M. Kulesza, Ustawa o gospodarce komunalnej. Komentarz, Warszawa 2002, s. 93-94; M. Szydło, op. cit., s. 417; J. J. Zięty, Ustawa o gospodarce komunalnej. Komentarz, Warszawa 2012, s. 105-106.

${ }^{44}$ Zob. J. Rifkin, Trzecia rewolucja przemystowa, Katowice 2012, passim. 
Na podstawie wskazanej powyżej definicji można stwierdzić, że podstawowymi elementami przesądzającymi o możliwości zakwalifikowania danego podmiotu jako wytwórcy jest fakt ulokowania jego siedziby bądź miejsca zamieszkania $\mathrm{w}$ określonym przez ustawę miejscu oraz dysponowanie przez ten podmiot odpowiednią instalacją OZE, wytwarzającą m.in. energię elektryczną z OZE.

Definicja legalna pojęcia instalacji OZE została uregulowana w art. 2 pkt 13 u.o.z.e. Zgodnie z definicją przez instalacje OZE rozumieć należy m.in. instalację stanowiąca wyodrębniony zespół urządzeń służących do wytwarzania energii i wyprowadzania mocy, w których energia elektryczna lub ciepło są wytwarzane z odnawialnych źródeł energii. W pierwotnej wersji u.o.z.e. ${ }^{45}$ definicja ta miała bardziej złożony charakter, zrelatywizowany do jednego miejsca przyłączenia urządzeń wytwórczych do sieci elektroenergetycznej oraz konieczności wykorzystania tylko jednego rodzaju odnawialnych źródeł energii. W aktualnym brzmieniu $^{46}$ definicja instalacji OZE pomija wskazane powyżej elementy, co z jednej strony nadaje jej bardziej ogólny i uniwersalny charakter, z drugiej natomiast - czyni ją trudniejsza przy interpretacji dokonywanej na potrzeby konkretnego stanu faktycznego. Negatywnie należy zatem ocenić rezygnację z najbardziej obiektywnego elementu definicji wskazujacego na jedno miejsce przyłączenia instalacji OZE do sieci, gdyż bez tego elementu trudniejsze staje się zadanie dostatecznego wyodrębnienia danego zespołu urządzeń tworzących instalację OZE. Skonstruowanie definicji legalnej, wymagającej wyodrębnienia urządzeń wytwórczych tworzących instalację OZE bez precyzyjnego wskazania elementów umożliwiających owe wyodrębnienie tworzy zagrożenie, że spory w tym zakresie będą musiały być rozstrzygane ad casum, co nie powinno charakteryzować przepisów prawnych umożliwiajacych korzystanie z dozwolonej pomocy publicznej. Podkreślenia wymaga, że inne pojęcia definiujące szczególne, ze względu na swoje cechy, rodzaje urządzeń wytwórczych w swojej treści zawsze odwołują się do pojęcia instalacji OZE. Tym samym pojęcie instalacji OZE stanowi pojęcie podstawowe dla innych pojęć istotnych w omawianym zakresie.

W zakresie wytwarzania energii elektrycznej ze źródeł odnawialnych $\mathrm{z}$ takimi uregulowaniami mamy do czynienia w szczególności w art. 2 pkt 19 u.o.z.e. definiującym mikroinstalację oraz w art. 2 pkt 18 u.o.z.e. definiującym pojęcie małej instalacji. Z powyższych uregulowań wynika to, że wytwórca może również wytwarzać energię elektryczna, wykorzystując inne, szczególne formy instalacji OZE. W tym aspekcie należy wskazać, że ustawodawca relatywizuje zasady i warunki, na jakich konkretne podmioty moga prowadzić tego typu działalność od wielkości danej instalacji OZE, a w konsekwencji od ilości wytwarzanej przez nią energii elektrycznej. Generalnie można wskazać, że im mniejsza skala prowadzonej działalności, tym mniej wymogów formalnych musi spełnić dany wytwórca ${ }^{47}$. Abstrahując od kwestii wytwarzania

\footnotetext{
45 Ustawa z 20 lutego 2015 r. o odnawialnych źródłach energii, Dz. U. 2015, poz. 478 ze zm.

${ }^{46}$ Ustawa z 22 czerwca 2016 r. o zmianie ustawy o odnawialnych źródłach energii oraz niektórych innych ustaw, Dz. U. 2016, poz. 925.

${ }^{47} \mathrm{~W}$ szczególności, zgodnie z art. 4 ust. 1 u.o.z.e., osoby fizyczne nie wykonują działalności gospodarczej, jeżeli wytwarzają energię elektryczną w mikroinstalacji w celu jej zużycia na włas-
} 
energii elektrycznej przez osoby fizyczne ${ }^{48}$, należy stwierdzić, że co do zasady wytwarzanie energii elektrycznej $\mathrm{w}$ instalacjach OZE jest szczególnego rodzaju działalnościa gospodarczą, mającą na celu wytwarzanie szczególnego rodzaju dobra, jakim jest energia elektryczna wytworzona $\mathrm{z}$ odnawialnych źródeł energii ${ }^{49}$.

Dalsze przepisy u.o.z.e. doprecyzowują możliwość stosowania przez konkretnych wytwórców poszczególnych instrumentów wsparcia OZE. Tak więc po analizie przepisów dotyczących chociażby sprzedawcy zobowiązanego (art. 41 i 42 u.o.z.e.), zielonych certyfikatów (art. 44 i 45 u.o.z.e), a także przepisów dotyczących systemu aukcyjnego (art. 71 i n. u.o.z.e.) należy wskazać, że w zasadniczej części instrumenty te kierowane są do przedsiębiorców. Jednocześnie chociażby w art. 41 ust. 1 pkt 2 u.o.z.e. ustawodawca wskazuje, że przedsiębiorca jest tylko taki podmiot, który posiada ten status w rozumieniu ustawy z 2 lipca 2004 r. o swobodzie działalności gospodarczej. Potwierdzeniem wymienionej tezy sa przepisy regulujące kwestię administracyjnoprawnej reglamentacji wytwarzania energii elektrycznej z instalacji $\mathrm{OZE}^{50}$, które co do zasady wymagaja, aby wytwórca legitymował się statusem przedsiębiorcy ${ }^{51}$. Zgodnie bowiem z ogólnymi przepisami dotyczacymi zasad wytwarzania energii elektrycznej uregulowanymi $\mathrm{w}$ art. 3 u.o.z.e. $\mathrm{w}$ zw. z art. 32 i n. u.p.e. oraz 46 i n. u.s.d.g. wyrażającymi obowiązek koncesyjny, a także tymi dotyczącymi prowadzenia działalności regulowanej w małej instalacji, o których mowa w art. 7 i n. u.o.z.e. oraz 64 i n. u.s.d.g., działalność taka może być wykonywana jedynie przez przedsiębiorców w rozumieniu art. 4 ust. 1 u.s.d.g.

W związku z powyższym, aby gmina mogła uczestniczyć w systemie wsparcia OZE, musi ona powołać odrębny podmiot, który będzie kwalifikowany jako przedsiębiorca w rozumieniu przepisów u.s.d.g. Podmiotem takim może być w szczególności kapitałowa spółka komunalna, która będzie mogła uzyskać koncesję i w ten sposób prowadzić działalność gospodarczą opierającą się na instalacji OZE. Niemniej - chociaż ustawodawca explicite w art. 7 ust. 1 pkt 4 u.s.g. wskazał, że do zadań gminy należy zaopatrzenie w energię elektryczna - gmina jako osoba prawna nie może bezpośrednio uczestniczyć w systemie wsparcia OZE. Wniosek taki, niezależnie od możliwości uznania gminy za przedsiębiorcę w rozumieniu art. 4 u.s.g.d. w konkretnym, „cząstkowym” czy „fragmentarycznym” ujęciu, wynika z tego, że samo wytwarzanie energii elektrycznej z OZE wykracza poza działalność o charakterze użyteczności publicz-

\footnotetext{
ne potrzeby, a jej niewykorzystaną nadwyżkę wprowadzają do sieci dystrybucyjnej i sprzedają sprzedawcy zobowiązanemu (tzw. prosumenci).

${ }^{48} \mathrm{~W}$ dalszej części opracowania celowo pominięto kwestie związane z wytwarzaniem energii z instalacji OZE przez osoby fizyczne, gdyż niniejsze opracowanie poświęcone jest działalności gminy w sektorze OZE.

${ }^{49}$ Zob. definicja legalna pojęcia „odnawialne źródło energii” zawarta w art. 3 pkt 22 u.o.z.e.

${ }^{50} \mathrm{~W}$ art. 3 u.o.z.e. ustawodawca wskazał na konieczność uzyskania w określonych okolicznościach koncesji na wytwarzanie energii elektrycznej z instalacji OZE. Ponadto szczególne przypadki uregulowano także w przepisach rozdziału 2 u.o.z.e., dotyczącego m.in. zasad i warunków wykonywania działalności w zakresie wytwarzania energii elektrycznej przez przedsiębiorców w mikroinstalacjach oraz małych instalacjach.

${ }^{51}$ Jak już wskazywano, wyjątkiem od tej zasady jest wytwarzanie energii przez prosumenta w mikroinstalacji, o którym mowa w art. 4 ust. 1 i 2 u.o.z.e.
} 
nej, a w związku z tym podlega wyżej opisanym ograniczeniom wskazanym w art. 10 u.g.k.

Zdaniem autorów wytwarzanie „czystej” energii elektrycznej z instalacji OZE należy zakwalifikować jako działalność ważną dla rozwoju każdej gminy, a w związku z tym może ona podlegać regulacji zawartej w art. 10 ust. 3 u.g.k. Działalność gminy w sektorze OZE jest dla niej ważna nie tylko z czysto gospodarczych pobudek. Samorządowe inwestycje w OZE pozwolą przyczynić się do rozwoju gminy przez poprawę warunków środowiskowych i zdrowotnych ${ }^{52}$, zarówno w aspekcie regionalnym, jak i ogólnokrajowym. W związku z powyższym należy uznać, że gminy powinny mieć możliwość posiadania akcji lub udziałów spółek wytwarzających energię z OZE, a nawet winny mieć możliwość tworzenia takich spółek, powołując się na ważny dla rozwoju gminy przedmiot działalności takich podmiotów.

\section{PODSUMOWANIE}

Przeprowadzone w niniejszej pracy badania pozwalają stwierdzić, że przepisy prawa unijnego nie sprzeciwiają się możliwości wytwarzania energii z OZE przez jednostki samorządu terytorialnego, w tym przez gminę. Co więcej, działalność gminy w sektorze energetycznym została uznana przez orzecznictwo TSUE za działalność gospodarczą prowadzoną przez przedsiębiorstwa, do której zastosowanie mają ogólne reguły konkurencji zawarte w art. 101109 TfUE, w tym w szczególności przepisy dotyczące udzielania dozwolonej pomocy publicznej53. Przepisy te uzależniają przyznanie pomocy od faktycznego prowadzenia działalności gospodarczej podlegającej wsparciu, jednocześnie bardzo szeroko ujmując kwestie podmiotu prowadzącego tę działalność.

Prawodawca unijny w art. 3 ust. 3 pkt a dyrektywy 2009/28/WE przyznał poszczególnym państwom członkowskim UE możliwość tworzenia własnych systemów wsparcia wytwarzania energii z OZE, którego niezbędne mechanizmy pomocowe mają zrównoważyć negatywne skutki wytwarzania energii przy wykorzystaniu innowacyjnego rodzaju technologii. W związku z powyższym zagadnienia wsparcia wytwórców energii z OZE, a także zasady i warunki prowadzenia działalności gospodarczej przez gminy, w tym wytwarzania energii z OZE zostały uregulowane w prawodawstwie krajowym.

Pośród zadań własnych gminy wymienionych w art. 7 ust. 1 pkt 3 u.s.g. ustawodawca expressis verbis wymienia realizację zadań własnych samorządu terytorialnego polegających na zaopatrywaniu mieszkańców gminy w energię elektryczną. Wydaje się zatem, że działalność gminy w sferze wytwarzania energii elektrycznej z OZE można uznać za pozostającą w sferze zadań własnych. Niemniej skoro gmina nie realizuje tych zadań, bezpośrednio świadcząc usługi powszechnie dostępne, nie można ich uznać za zadania o charakterze

${ }^{52} \mathrm{~W}$ tym aspekcie warto wskazać na działania podejmowane przez gminy mające na celu przeciwdziałanie zanieczyszczeniu powietrza i polityce antysmogowej.

${ }^{53}$ Por. S. Dudzik, Pomoc państwa..., Lex Omega, nr 33918. 
użyteczności publicznej. W związku z powyższym prowadzenie działalności gospodarczej przez gminy polegające na wytwarzaniu energii elektrycznej z OZE wykracza poza ramy użyteczności publicznej.

Szczególne zasady i formy organizacyjno-prawne prowadzenia przez gminy działalności gospodarczej poza sfera użyteczności publicznej określa art. 10 u.g.k. Wśród szczegółowych rozwiązań na uwagę zasługuje art. 10 ust. 3 u.g.k. wskazujący, że gmina może prowadzić działalność gospodarczą w formie spółek prawa handlowego, jeżeli są one ważne dla rozwoju gminy. Chociaż w doktrynie wskazuje się na konieczność zawężającej interpretacji tego przepisu, to warto wskazać, że w przypadku OZE nie chodzi jedynie o rozwój czysto gospodarczy, ale również o realizację innych społecznie doniosłych celów związanych chociażby z zagwarantowaniem bezpieczeństwa energetycznego, ochrona środowiska naturalnego, obniżeniem poziomu emisji dwutlenku węgla do atmosfery (dekarbonizacja energetyki) i walką ze zmianami klimatu, czy ochrona zdrowia i polepszeniem komfortu życia mieszkańców gminy. Pozwala to na interpretację art. 10 ust. 3 u.g.k. z aksjologicznego i prakseologicznego punktu widzenia życzliwą dla możliwości tworzenia przez gminę spółek (oraz posiadania akcji i udziałów w takich spółkach) wytwarzajacych energię z OZE.

Warto wskazać, że przepisy u.o.z.e. regulujące warunki i zasady wspierania wytwarzania energii elektrycznej z OZE, tak jak właściwe przepisy unijne, odwołuja się przede wszystkim do przedmiotowego ujęcia prowadzenia tego typu działalności gospodarczej. Wsparcie przyznawane jest podmiotom, które prowadzą działalność polegajaccą na wytwarzaniu energii elektrycznej z instalacji OZE, bez ich zróżnicowania na przedsiębiorców prywatnych czy publicznych.

Zatem skoro ustawodawca wśród zadań własnych gminy wskazał zadania gospodarcze związane z dostarczaniem energii elektrycznej, to zainteresowane gminy na podstawie art. 10 ust. 3 u.g.k. mogłyby powołać komunalna spółkę prawa handlowego, która spełniając stosowne warunki przepisane w u.o.z.e., stałaby się wytwórcą energii z instalacji OZE. W związku z powyższym gminy mogłyby, choć pośrednio, uczestniczyć w planowanym systemie wsparcia oraz promowania energii odnawialnej. Ponadto zaangażowanie gmin w wytwarzanie energii z OZE w znaczącym stopniu mogłoby też przyczynić się do osiagnięcia potencjalnie zagrożonego celu 15-procentowego udziału odnawialnej energii w całkowitym krajowym zużyciu energii w $2020 r .{ }^{54}$

dr hab. Eryk Kosinski

Profesor Uniwersytetu im. Adama Mickiewicza w Poznaniu

oraz visiting profesor Uniwersytetu Politechnicznego im. Piotra Wielkiego

$w$ Petersburgu, Federacja Rosyjska

erykk@amu.edu.pl

mgr Michat Trupkiewicz

Uniwersytet im. Adama Mickiewicza w Poznaniu

marcin.trupkiewicz@amu.edu.pl

${ }^{54}$ Por. G. Wiśniewski, Jak Polska realizuje unijne zobowiazania dot. energii z OZE?, http:// www.cire.pl/item,122915,13,0,0,1,0,0,jak-polska-realizuje-unijne-zobowiazania-dot-energii-z-oze. html\#komentarz [dostęp: 18.02.2015]. 


\title{
A MUNICIPALITY (GMINA) AS PART OF THE SUPPORT SYSTEM FOR GENERATION OF ELECTRICITY FROM RENEWABLE ENERGY SOURCES
}

\author{
Sum mary
}

The article describes certain aspects of the system of state support for renewable energy sources as a permissible state aid provided to undertakings. Under EU legal regulations such financial support may be furnished to an entity which conducts an economic activity. Setting precise rules is left to the Member States. Under Polish law the economic activity of a municipality is regulated by special legislation, while provision and generation of electricity from renewable energy sources remains within the scope of the allowable activity of municipalities. However, municipalities may only engage directly in the public utility sector, which means the organisation and satisfaction of the collective needs of a community. It is worth noting that outside the public utility sector they are free to create municipal companies to conduct economic activity, but only if certain legal conditions are met (see the Act on Municipal Economy of 1996). One of those conditions is taking up an activity which is crucial for the development of the municipality (Article 10 section 3 of the Act). It seems that generation of energy from renewable energy sources can easily be regarded as crucial for the development of a municipality. Consequently, a municipality may participate in the renewable energy sources support system by setting up a company which will be a producer of energy from renewable energy sources as referred to in the provisions of the Act on Renewable Energy Sources of 2015. 
